\title{
Charles Thibault
}

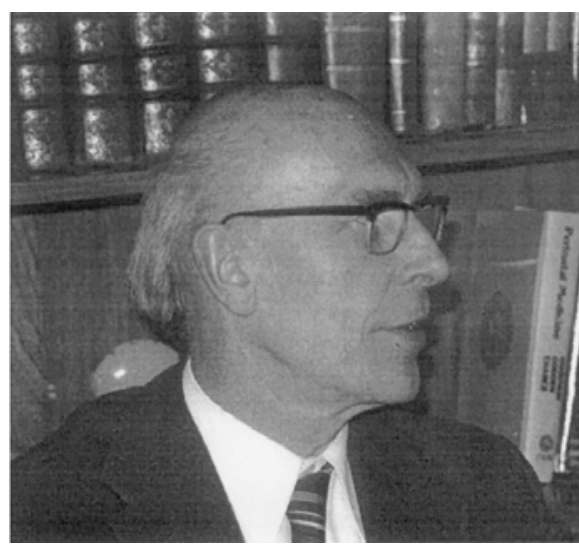

Throughout his life, Charles Thibault was always fascinated by research. During the 1950's, at the Institut National de la Recherche Agronomique, he developed one of the first laboratories of the Animal Physiology Department, of which he later became the Department head. Later, he had other research administrator tasks as the President of the Centre National de la Recherche Scientifique. As a Professor of Reproduction Physiology at the Université Paris 6, he was always attentive to include the most recent research results in his classes. He was advisor for a very large number of doctorate students and many students owe him for helping them to become researchers. But above all, he was fascinated by research and was creative. He was responsible for the first in vitro fertilisations in domestic mammals. His scientific knowledge and his intellectual vivacity always impressed his colleagues in the many congresses in which he participated and he was, very justly, honoured with many distinctions. But he also knew how to walk out of his laboratory and take part in debates of the society against, notably, narrow minded positions on birth regulation and systematic medicalization of human procreation. Fascinated by scientific writing and publication, the Professor Charles Thibault spent a large part of his activities publishing and diffusing his research results. In 1961, with André François he founded the journal "Annales de Biologie Animale, Biochimie, Biophysique (ABABB)", mainly dedicated to papers in animal physiology and nutrition biochemistry submitted by researchers at INRA. This journal rapidly became a success and its pages were quickly opened to other research organisations. Charles Thibault, when handing over his position as Editor-in-Chief of the journal in 1981, recognised the importance of reorientating the journal, which he made public by a change in its title (Reproduction, Nutrition, Development), and increasing its readability and diffusion. He was an intransigent negotiator with the Editors, a respected counsellor to the authors, and he was always preoccupied by the quality of the journal, not only with its scientific selection of the manuscripts but also with their presentation. He always found an undissimulated pleasure in letting his fingers walk through the latest issue of the journal and "touching the paper" that was a product of several months of shared work. In publication as elsewhere, his candour, his enthusiasm and his scientific rigour led him to be wary of preconceived ideas and to renounce diverse theories that were not supported by incontestable experimental results. His colleagues still remember the energy he spent directing the new edition of "Reproduction chez les Mammifères et l'Homme" in 2001, the only French work in this domain that has been published recently. Our journal is honoured to publish here his last review article on human cloning.

The editors of RND regret that this master who they profoundly respected and who was always natural and spontaneous, will no longer be around to give them council and encouragement.

The old and current Editors of Reproduction Nutrition Development 
Review

\title{
Recent data on the development of cloned embryos derived from reconstructed eggs with adult cells
}

\author{
Charles THIBAULT*
}

\begin{abstract}
UMR Biologie du Développement et Reproduction, Institut National de la Recherche Agronomique, 78352 Jouy-en-Josas Cedex, France
\end{abstract}

(Received 3 February 2003; accepted 15 June 2003)

\begin{abstract}
Production of cloned embryos by nuclear transfer from adult somatic cells is a novel and promising technique in animal biotechnology. In spite of numerous reported viable offspring in various species, the efficiency of the technique remains very low. Embryonic and fetal mortality occurs all along pregnancy and during the peri-natal life, even months after birth. Both embryonic and placental dysfunctions might be involved. However the precise causes of such developmental failures are still unknown. In the present review, we report data from different studies which described the main defaults which have been observed after embryonic cloning in various species. The putative molecular and cellular causes of these developmental failures are discussed.
\end{abstract}

cloning / development failure / nuclear reprogramming

\section{GENERAL SURVEY}

Many mammals have been cloned but the ratio between the number of reconstructed embryos transferred and the number of viable offspring, remains very low, in spite of a broad spectrum of investigations. Most of the embryos die during the pregnancies, and even after parturition. It is rather puzzling, however, those that survive are physiologically normal as shown [1] in a large study on bovine cloning. From 2170 recipients receiving 1 to 3 cloned embryos, 117 calves were born (5.4\%), 82 survived and developed as adults $(3.8 \%$ of all pregnant recipients, $2 \%$ of the total number of embryos transferred). Cumulative abortion rates reach $75 \%$. Interestingly, prior to abortion, the growth rate of aborted fetuses was similar to those that were not aborted. This observation suggests that the trophectoderm and then the placenta are mainly responsible for embryonic death. However, since many offspring die after parturition, embryo deficiencies are also a cause of abortion.

Surviving cloned heifers started to display signs of reaching puberty at 10-11 months. All of the 22 cloned heifers that were inseminated became pregnant. Age at calving was 23-25 months, similar to non-cloned cattle. The milk from cloned cattle appeared to be

\footnotetext{
* Deceased on 20th August 2003.

Corresponding author: Michel Guillomot: guill@jouy.inra.fr
} 
Table I. Evolution of 240 cattle pregnancies after transfer of day 7 blastocysts according to the origin of the cell donor (from Heyman et al. [3]).

\begin{tabular}{lcccc}
\hline $\begin{array}{l}\text { Pregnant recipients } \\
\text { at the following } \\
\text { days or months }\end{array}$ & $\begin{array}{c}\text { Adult somatic } \\
\text { cell } \\
\text { 133 recipients }\end{array}$ & $\begin{array}{c}\text { Fetal somatic } \\
\text { cell } \\
\text { 40 recipients }\end{array}$ & $\begin{array}{c}\text { Embryonic } \\
\text { cell } \\
\text { 67 recipients }\end{array}$ & $\begin{array}{c}\text { In vitro fertilized } \\
\text { embryos } \\
51 \text { recipients }\end{array}$ \\
\hline Day 21 & $74 / 133$ & $23 / 40$ & $42 / 67$ & $32 / 51$ \\
Day 35 & $45 / 133$ & $11 / 40$ & $33 / 67$ & $27 / 51$ \\
Day 50 & $36 / 133$ & $9 / 40$ & $28 / 67$ & $26 / 51$ \\
Day 70 & $19 / 133$ & $9 / 40$ & $25 / 67$ & $25 / 51$ \\
Day 90 & $16 / 133$ & $9 / 40$ & $23 / 67$ & $24 / 51$ \\
3-5 months & $13 / 133$ & $9 / 40$ & $23 / 67$ & $24 / 51$ \\
5-7 months & $10 / 133$ & $7 / 40$ & $22 / 67$ & $24 / 51$ \\
7-9 months & $9 / 133$ & $6 / 40$ & $22 / 67$ & $24 / 51$ \\
No. calves born (\%) & $9 / 133(6.8 \%)$ & $6 / 40(15 \%)$ & $23 / 67$ & $25 / 51(49 \%)$ \\
& & & $(34.3 \%)$ & twin calving \\
\hline
\end{tabular}

normal. An aberrant epigenetic modification (large offspring syndrome) has, however, been observed in living cloned mice, although fertile [2].

There is a general agreement first that embryonic mortality increases with the age of the donor from the embryo to the adult, and second that embryonic mortality persists all along gestation. An example is given in Table I.

This table clearly shows that the late fetal losses (in ital.) from day 90 to day 282 are high when donor cells are from adult animals [3].

Renard et al. [4] have given a very complete overview of the biological aspects of cloning and clones. They give new data, mainly devoted to cattle, and discuss on the present results and future prospects.

The present review focuses attention on the causes of abnormal development of cloned embryos.

\section{NUCLEAR REPROGRAMMING}

\subsection{Role of GV content}

At what stage of maturity are oocytes able to reprogram a somatic nucleus? Gao et al. [5] studied the capacity of immature (GV) or premature (pro-M I) mouse cytoplasm to reprogram a nucleus of an embryonic stem cell. Control oocytes were in M II before nuclear transfer (Tab. II).

Thirty minutes after the nuclear transfer in all three types of cytoplasm, a spindle starts to organize and condensed chromosomes are formed. In GV ooplasm, chromosomes appear distributed into the cytoplasm and are neither organized on the spindle nor form a pronucleus. In contrast, in Pro-M I cytoplasm (GVBD stage), condensed chromosomes reach the spindle and form a metaphase plate similar to the control M II as shown by the immunofluorescence technique, and after activation a pronucleus is formed. Only $8.1 \%$ of pro-M I reconstructed embryos developed to the morula-blastocyst stage. In contrast, $53.5 \%$ of M II reconstructed embryos reached this stage and 6 pups are recovered from the surrogate mothers at 19.5 days post coitum. Moreover, during the $5 \mathrm{~h}$ following transfer and activation, the content of microfilaments in the cortex of GV oocytes (as well as Pro-M I oocytes) was lower than in the cortex of M II ooplasm. It seems that GV material is essential for nuclear remodelling after nuclear transfer: In GV-ooplasm, after activation, reconstructed oocytes could not form pseudopronuclei, and the chromosomes remained 
Table II. Ooplasm status and per cent of blastocysts and fetuses obtained after nuclear transfer (Gao et al. [5]).

\begin{tabular}{lccccc}
\hline $\begin{array}{l}\text { Enucleation } \\
\text { stage }\end{array}$ & $\begin{array}{c}\text { No. oocytes } \\
\text { surviving } \\
\text { injection and } \\
\text { activation }\end{array}$ & $\begin{array}{c}\text { No. and } \\
(\%) \\
\text { activated } \\
\text { eggs }\end{array}$ & $\begin{array}{c}\text { No. and } \\
(\%) \\
\text { cleaved } \\
\text { eggs }\end{array}$ & $\begin{array}{c}\text { No. and } \\
(\%) \text { morula / } \\
\text { blastocysts } \\
\text { developed }\end{array}$ & $\begin{array}{c}\text { No. } \\
\text { transferred } \\
\text { embryos } \\
\text { (recipients) }\end{array}$ \\
\hline GV & 75 & 0 & & & \\
Pro-M I & 86 & $85(98.8)$ & $42(48.8)$ & $7(8.1)$ & \\
M II & 221 & $213(96.4)$ & $162(76.1)$ & $114(53.5)^{*}$ & $114(11)^{+}$ \\
\hline
\end{tabular}

${ }^{+} 6$ pups were recovered from surrogate mothers at 19.5 days postcoitum.

$* P<0.01$.

condensed. The factor(s) released by GV, after GVBD, are unknown but seem in relation with chromosomes and spindle recognition and with nucleus reconstruction.

\subsection{Chromatin remodeling}

Three types of recipient enucleated oocytes have been used for nuclear transfer: non-activated oocytes (TA), previously activated oocytes (AT) and ageing oocytes in which the MPF level is decreasing.

Taking normal development as a proof of nuclear reprogramming, Tani et al. [6] examined the in vitro developmental potential of TA and AT enucleated bovine ova receiving cumulus cell nuclei at various stages of the cell cycle: cycling, G0/G1, G1, S, G2 and $\mathrm{M}$.

The development potential of nuclear transfer ova was clearly different depending on the condition of the recipient ova.

When activated ova were used as the recipient cytoplasm, none of the nucleartransferred ova receiving cumulus cell nuclei at any cell cycle stage, developed beyond the 8-cell morula stage. In contrast, 21 to $50 \%$ of non-activated ova receiving cumulus cell nuclei at all cell-cycle stages, except the $\mathrm{S}$ phase, and then activated, developed into blastocysts.
The blastocyst cell number was not significantly different among any group. (However, the numbers of cells given in Tab. I for 8-day blastocysts (from $70.7 \pm$ 29.4 to $86.3 \pm 31.8$ ) are much lower than those found in blastocysts obtained from in vitro or in vivo fertilization ( $\geq 200$ cells).)

Their studies demonstrate that after transfer of a somatic nucleus in a non activated ooplasm, the envelope of the somatic nucleus is broken and chromosomes are directly exposed to ooplasm allowing nuclear remodeling. In contrast, in activated ooplasm the nucleus remains unchanged.

Kim et al. [7] has made a similar conclusion in a mouse nuclear transfer experiment: there is $1 \%$ of morulae/blastocysts when cumulus cell nuclei are transferred after activation (AT) vs. $38.3 \%$ when transfer occurs before activation (TA). Moreover, they compared transcriptional activity and chromosome DNAse-1 sensitivity in TA and AT reconstructed ova. A basal transcription factor $($ TATA box binding protein $=$ TBP) was displaced from the condensed chromatin of transferred nuclei in the TA ooplasm. Such translocation of TBP was not observed in the AT embryos. In the TA embryos, DNAse-1 sensitivity was increased after nuclear transfer (2-fold, at $5 \mathrm{~h}$ postactivation), then decreased at $12 \mathrm{~h}$, while the sensitivity was not changed in AT embryos during the first-cell stage. The results suggest that the 
cytoplasm of activated mouse oocytes is inefficient for nuclear remodeling due to a failure of nuclear envelope breakdown which allows direct interaction of chromosomes with cytoplasmic factors.

\subsection{Structure of the DNA of the transferred nucleus}

Loi et al. [8] studied the resistance of DNA and centrioles of ovine granulosa cells (GC) heated to lethal temperatures. All nuclear proteins were denatured at 55 or $75^{\circ} \mathrm{C}$ and GC became nonviable, however, DNA remained able to be reprogrammed (Tab. III), (a functional centriole was postulated but not shown).

Unfolded and denatured proteins are more readily degraded by the oocyte proteolytic enzymes. Therefore, the oocyte reprogramming machinery might more readily process nucleoprotein complexes rendering the chromosomes more accessible to remodeling. However, the results remain low although slightly better than those obtained in ewes after nuclei somatic cell transfer (Tab. IV).

\subsection{Imprinting/epigenetic reprogramming. Methylation}

\subsubsection{Embryos from fertilized eggs}

Both the sperm and egg genomes are highly methylated and transcriptionally silent at the time of fertilization. Within only a few hours after fertilization, the paternal genome of the mouse embryo undergoes a drastic and active demethylation, whereas similar genome-wide demethylation of the maternal genome occurs progressively after

Table III. Heat denaturation of granulosa cell nucleoproteins and subsequent development after nuclear transfer (Loi et al. [8]).

\begin{tabular}{lccc}
\hline Nuclei from & Injected $(n)$ & Cultured $(n)$ & Blastocysts $(n$ and \%) \\
\hline GC, untreated & 241 & 227 & $25(11 \%)$ \\
GC, heated at $55^{\circ} \mathrm{C}$ & 470 & 336 & $47(14 \%)$ \\
GC, heated at $75^{\circ} \mathrm{C}$ & 242 & 146 & $41(28 \%)$ \\
Fertilized & - & 335 & $136(40.5 \%)$ \\
\hline
\end{tabular}

Table IV. The percentage of pregnant ewes decreased similarly whatever the treatment. However, no lamb was obtained with granulosa cells (GC) heated to $75^{\circ} \mathrm{C}$ (Loi et al. [8]).

\begin{tabular}{|c|c|c|c|c|c|}
\hline \multirow{2}{*}{ Nuclei from } & \multirow{2}{*}{$\begin{array}{l}\text { Blastocysts transferred } \\
\text { number of recipient } \\
\text { ewes (number of ewes) }\end{array}$} & \multicolumn{3}{|c|}{$\begin{array}{c}\text { No. and }(\%) \text { of ewes } \\
\text { pregnant }\end{array}$} & \multirow{2}{*}{$\begin{array}{l}\text { Lambs } \\
(n \text { and \%) }\end{array}$} \\
\hline & & at day 40 & at day 60 & at day 80 & \\
\hline GC untreated & $25(13)$ & $9(69 \%)$ & $5(38 \%)$ & $2(15 \%)$ & $2 / 25(8 \%)$ \\
\hline $\mathrm{GC}, 55^{\circ} \mathrm{C}$ & $40(19)$ & $15(79 \%)$ & $9(47 \%)$ & $5(26 \%)$ & $4 / 40(10 \%)$ \\
\hline $\mathrm{GC}, 75^{\circ} \mathrm{C}$ & $25(11)$ & $7(64 \%)$ & $5(45 \%)$ & $3(27 \%)$ & 0 \\
\hline Fertilized & $52(26)$ & $20(77 \%)$ & $18(69 \%)$ & $18(69 \%)$ & $23 / 52(44 \%)$ \\
\hline
\end{tabular}


the two-cell embryonic stage in the mouse. Both paternal and maternal genomes are equivalently under-demethylated at the morula and blastocyst stages and, thereafter, de novo methylated [9].

From the beginning of embryonic development, some genes, called imprinted genes, are inactivated either in the male or in the female genome by high methylation.

Kierszenbaum [10] has summarized our knowledge on imprinting and the occurrence of reprogrammation of imprinted genes after somatic nuclear transfer.

Genomic imprinting, an epigenetic form of gene regulation, determines the parent-dependant gene expression of marked or imprinted genes during gametogenesis and embryonic development. About 50 mammalian imprinted genes have been identified. Imprinting involves differential allele DNA hypermethylation in one sex cell lineage but not in the other. Primordial germ cells inherit biallelically imprinted genes from paternal and maternal origin and erase these imprints to start de novo monoallelic imprinting during gametogenesis.

Epigenetic paternalization is an ongoing process in the mitotically-dividing spermatogonial stem cell and is derived meiotically, dividing spermatocyte progeny to endow spermatozoa with imprinted alleles. Epigenetic maternalization is restricted to the oocyte growth phase and is unrelated to DNA replication since it takes place while the oocyte remains in the diplotene stage of meiotic prophase I.

Genomic methylation depends on the activity of DNA methyl transferases (DnmT). Methylation takes place mainly on the cystine residues that are present in dinucleotide motifs consisting of a 5' cytosine followed by a guanosine $(\mathrm{CpG})$. DNA methylation patterns are regulated during development by three distinct methyltransferases, Dnmt-1, Dnmt-3a and Dnmt-3b. Dnmt- 1 is essentially a house-keeping methyltransferase required for maintaining tissue specific methylation patterns as shown by mutations in the Dnmt-1 gene, which result in global genome demethylation and embryo lethality. Dnmt-3a and Dnmt-3b are required for de novo methylation of embryonic stem cells and early post implantation embryos.

How do these methyltransferases recognise the target sequences in candidate genes in the male and female genome?

A partial answer has been given by the discovery of the role of a protein sharing homology with methyltransferases but lacking enzyme activity, the Dnmt 3L. Hata et al. [11] have shown that this protein seems necessary for targeting methyltransferases to DNA specific sequences. Dnmt3L expression was detected in oocytes, in ES cells and in the chorion. The expression pattern of Dnmt $3 L$ in all these cells and tissues is strikingly similar to that of Dnmt3a and Dnmt3b. Dnmt- $3 L^{-1-}$ female mice had normal reproductive functions but no live pups were born. They died around E10,5 with head and neural abnormalities and under developed placentas. Although Dnmt3L had no methyltransferase activity, the methylation status of differentially methylated regions of some maternally imprinted genes were almost completely demethylated. The same genes were also unmethylated in Dnmt $3 a^{--}$and Dnmt $3 b^{-1-}$ mice.

Unlike the female Dnmt $3 L^{-/-}$mice, the methylation of male imprinted genes, H19 and Rasgrf1, were unaffected. However, the Dnmt3L $L^{-1-}$ male was sterile: the spermatogonia failed to differentiate into spermatocytes: the lack of Dnmt3L appears to prevent spermatogonial progeny from undergoing differentiation and meiosis.

\subsubsection{Cloned embryos}

To get a better understanding of global methylation differences associated with the development of nuclear transfer generated cattle, Cezar et al. [12] analyzed the genome-wide methylation status of 9 spontaneous aborted cloned fetuses (2-, 2.5-, 6-, 
Table V. Genomic cytosine methylation content of fetal and adult genomes detected by reverse phase HPLC (Cezar et al. [12]).

\begin{tabular}{|c|c|c|}
\hline Group & Number of animals & $\begin{array}{c}\% \text { of } \\
5^{\mathrm{m}} \mathrm{C} /\left(5^{\mathrm{m}} \mathrm{C}+\mathrm{C}\right)^{*}\end{array}$ \\
\hline Aborted & 9 & $P<0.005$ \\
\hline Cloned fetuses & 7 & $P<0.001$ \\
\hline In vivo fetuses & 6 & 29 \\
\hline IVF fetuses & 4 & 27 \\
\hline Adult clones & 11 & 32 \\
\hline In vivo adult & 4 & 29 \\
\hline
\end{tabular}

* Results were expressed in \% of methyl cytidine/total cytidine.

7-month-old), 7 cloned normal fetuses recovered from ongoing normal pregnancies (\# 2 months old), 4 IVF foetuses (1.5-, 2-months old), 6 fetuses generated by artificial insemination (2-months old), 11 adult clones and 4 adults from natural reproduction (Tab. V).

The results indicated an extensive hypomethylation of DNA in the spontaneously aborted clones $(P<0.001)$ and a significant $(P<0.005)$ reduced methylation in living cloned fetuses compared with in vivo fetuses. There was no difference between adult clones and in vivo adults (Tab. IV). This implies that the survivability of cloned cattle may be closely related to the global methylation status.

Excessive growth in cloned living animals might be due to a wrong imprinting of genes involved in body weight regulation. Tamashiro et al. [2] studied the fate of cloned mice which remained alive, but showed growth abnormalities (large offspring syndrome and obesity). Leptin and insulin levels were much higher than in the control (7- and 3 -fold respectively) but similar to those of spontaneous obese mice in which either the $o b$ gene or its $d b$ receptor was mutated. However, the cloned mice were fertile and their offspring were of normal body weight. This indicates that gene dysfunction (hypomethylation of one parental allele) in cloned mice might be of epigenetic nature.

\section{CAUSES OF EMBRYONIC AND FETAL DEATHS: MORPHOLOGICAL ABNORMALITIES, AND CELLULAR AND GENETIC
DEFECTS}

Extensive studies have been developed to find out the causes of embryonic loss and to overcome the discouraging percentage of living young obtained, whatever the cloning procedures used. At present, it seems that defective mechanisms take place very early in development, although their consequences may occur along pregnancy and even some days or weeks after birth. Comparative studies between embryos from nuclear transfer (NT), in vitro fertilization (IVF), intra cytoplasmic sperm insemination (ICSI), parthenogenesis, and in vivo fertilized and developed embryos (IFD = in vivo fertilization and development), were performed to possibly identify the differences during the beginning of development.

\subsection{Growth of the inner cell mass and trophectoderm}

Rybouchkin et al. [13] studied the potential of the development of cloned mouse embryos in comparison with the potential of ICSI embryos and parthenogenetic embryos. They demonstrated that the capacity of reconstituted eggs to develop to the blastocyst 
stage (29\%) was significantly lower than that of ICSI or parthenogenetic embryos (95\% and $92 \%$ respectively). Cloned blastocysts had a significantly lower mean number of cells in the ICM (9) and trophectoderm (52) than did their counterparts (31 and 143 for ICSI; 21 and 92 for parthenogenetic blastocysts). This correlated with a significantly higher proportion of dead cells in the cloned blastocysts.

Koo et al. [14] studied allocations of the two different cell lineages of the bovine blastocysts, the inner cell mass (ICM), and the trophectoderm (TE).

Total cell numbers as well as the number of TE cells, were significantly smaller in IVF and NT blastocysts than in control in vivo blastocysts of the same age while ICM cell numbers were identical (Tab. VI). These results suggest that NT embryos having fewer TE cells at the blastocyst stage might form smaller placentas, eventually leading to fetal loss (Tab. VI).

\subsection{Abnormal development of the placenta}

A high incidence of placental abnormalities was observed during gestation: placentas were either overgrown (mouse), underdeveloped (bovine, sheep) or abnormally developed.

\subsubsection{Overgrowth}

In the mouse, Wakayama and Yanagimachi [15] compared the weight of placentas at term from "cloned" fetuses and "in vivo fertilized" fetuses. There were differences according to the origin of the donor cells (cumulus, ovary or testis, skin, and ES cells) between $0.34 \pm 0.07 \mathrm{~g}$ to $0.19 \pm 0.07 \mathrm{~g}$ but whatever the origin of the donor cell, these weights were significantly higher $(P<0.01)$ than the placenta of control "in vivo fertilized" fetuses $(0.15 \pm 0.03 \mathrm{~g}$ for male and $0.12 \pm 0.02 \mathrm{~g}$ for female fetuses). Ono et al. [16] gave similar values $(0.36-0.29 \mathrm{~g}$ and $0.13 \mathrm{~g})$. This placentomegaly is caused by an expansion of the spongiotrophoblast with an increased number of glycogen cells and an enlargement of trophoblastic cells. Ono et al. [16], Ogura et al. [17], Suemizu et al. [18], and Tanaka et al. [19] observed placental abnormalities from embryos that were derived through other micromanipulation techniques (ICSI, aggregation chimeras, pronuclear exchange) but expansion of the basal layer with marked proliferation of glycogen cells is the only phenotype that is unique to cloning. Expression of 3 imprinted genes (IGF-2 (paternally expressed), $I G F-2 r$ and $P 57^{K p i 2}$ (maternally expressed)) is slightly reduced apparently due to the reduced proportion of the labyrinth layer and not to a change in transcriptional activity [19]. Why

Table VI. No. of cells in 7-day-old bovine blastocysts from in vivo and in vitro fertilization, and nuclear transfer (Koo DB et al. [14]).

\begin{tabular}{lccccc}
\hline \multirow{2}{*}{ Group } & $\begin{array}{c}\text { No. of } \\
\text { blastocysts } \\
\text { examined }\end{array}$ & ICM & TE & Total & ICM / ICM + TE \\
\cline { 3 - 6 } & 26 & $42.3 \pm 10.5$ & $80.5 \pm 19.5$ & $122.5 \pm 21.6$ & $34.9 \pm 8.9$ \\
In vivo & 52 & $45.6 \pm 18.4$ & $62.4 \pm 26.3^{* *}$ & $108.2 \pm 33.3^{* *}$ & $42.6 \pm 14.9^{* *}$ \\
In vitro & 55 & $48.6 \pm 25$ & $49.5 \pm 1.5^{*}$ & $98.0 \pm 44.3^{* *}$ & $50.1 \pm 17.9^{* *}$ \\
\hline
\end{tabular}

$* P<0.01 ; * * P<0.05$. 
and how the spongiotrophoblast layer expands, remains unclear.

In cloned mice, most concepti were lost by 10 days of pregnancy, that is before the hemochorial placenta starts to function in the mouse. Given this fact, the late placenta phenotype that these authors described seems unlikely to be a cause of the embryonic mortality.

Inoue et al. [20] have shown that while the levels for imprinted genes Igf2, Igf2r and $H 19$ were within the control range, there was a significant reduction of mRNA levels of three imprinted genes and four nonimprinted genes in the placenta of both Sertoli cell- and cumulus cell-derived clones compared with the controls. In contrast, the corresponding cloned fetuses exhibited steady state mRNA levels for these genes within the control range. Thus the placenta is more affected than the fetus.

\subsubsection{Hypotrophy}

In cattle, at day 30 of pregnancy, histological examination reveals the presence of placentomes and a tenuous attachment of maternal and fetal epithelia. At this period, Hill et al. [21] found no significant difference between pregnancy rates for recipients that carried cloned fetuses and recipients carrying in vivo or in vitro fertilized fetuses. In cloned pregnancies, a high level of embryonic deaths occurs after day 30 . Whereas $100 \%$ of the control fetuses survived at day 90 only $19 \%$ of the cloned fetuses present on day 30, survived. Out of 6 placentas from NT embryos, 4 were abnormally developed (hypotrophy, poor vascularization, rudimentary cotyledons).

\subsubsection{Abnormal placentation}

In cattle, placentas from clones undergoing an abnormal pregnancy show a lower number of placentomes than those from in vitro fertilization (69 versus 99) but their mean weight is higher: $144.3 \pm 21.4 \mathrm{~g}$ in abnormal cloned fetuses and $72.9 \pm 4.8 \mathrm{~g}$ in normally developed cloned fetuses versus $33.6 \mathrm{~g}$ in two normal in vitro produced fetuses [22]. The large placentomes are oedematous. Studies by ultrasonography during gestation allow to visualize these large placentomes and to predict abortion [3]

Reduction of the numbers of placentomes seems to indicate that the placenta at the time of implantation possesses an insufficient number of molecular sites to recognize all uterine caruncles.

\subsection{Immunological status}

Hill et al. [21] studied the potential for altered immunological status of cloned pregnancies to be a contributing factor of embryonic loss. Expression of the major histocompatibility complex class I (MHC-I) by trophoblast cells and distribution of endometrial T-lymphocytes were investigated.

In cattle, at the beginning of a natural pregnancy when the intimate contact between endometrium and chorioallantois is initiated, MHC-I expression is normally suppressed. In contrast, in eight cloned pregnancies, all derived from the same fetal cell line, and examined at 5 weeks (6), 7 weeks (1) and 8 weeks (1), all 8 cloned placentas displayed trophoblast MHC-I expression which varied within clones, from 17.9 to $56.5 \%$ of the trophoblast cells. None of the 8 controls (4-7 weeks old) showed MHC-I expression.

In the cloned pregnancies the numbers of T-lymphocyte CD3+ were higher in the endometrium compared with the controls. Moreover, large aggregates of T-cells were frequently observed in addition to increased numbers of diffusely spread sub-epithelial lymphocytes. The observed expression of MHC I in cloned pregnancies is likely to have induced a maternal lymphocytic response that would be detrimental to maintaining the cloned pregnancies: 4 alive, 3 dead at days 34-49 of pregnancy versus 
Table VII. Changes in cell telomere length of transferred nuclei, in somatic cells nuclei of cloned cattle (Lanza RP et al. [25]).

\begin{tabular}{|c|c|c|c|}
\hline Donor cell type & $\begin{array}{c}\text { Mean telomere } \\
\text { restriction fragment } \\
(\mathrm{kb}) \text { in transferred } \\
\text { nucleus }\end{array}$ & $\begin{array}{l}\text { Mean telomere } \\
\text { restriction fragment } \\
\text { in cloned cattle } \\
\text { cells }(\mathrm{kb})\end{array}$ & $\begin{array}{l}\text { Telomere length } \\
\text { change }(\mathrm{kb})\end{array}$ \\
\hline $\begin{array}{l}\text { Oviductal epithelial } \\
\text { cells from a } 13 \text {-yr-old } \\
\text { Holstein cow }\end{array}$ & 15.2 & 13 (12.5 to 13.7$)$ & $\begin{array}{c}-2.1 \\
(-1.5 \text { to }-2.7)\end{array}$ \\
\hline $\begin{array}{l}\text { Mammary epithelial } \\
\text { cells from a } 13 \text {-yr-old } \\
\text { Holstein cow }\end{array}$ & 16.3 & 14.3 & -2.0 \\
\hline $\begin{array}{l}\text { Oviductal epithelial } \\
\text { cells from a 6-yr-old } \\
\text { Jersey cow }\end{array}$ & 16.9 & $15.5(14.9$ to 16.0$)$ & -1.5 \\
\hline $\begin{array}{l}\text { Muscle cells from a } \\
\text { 12-yr-old Japanese } \\
\text { Black bull }\end{array}$ & 20.1 & 19.7 (19.6 to 19.9$)$ & -0.3 \\
\hline $\begin{array}{l}\text { Skin fibroblasts from } \\
\text { a 2-yr-old Japanese } \\
\text { Black bull }\end{array}$ & 18.2 & $20.2(20.0$ to 20.4$)$ & +2.0 \\
\hline
\end{tabular}

7 alive, 1 dead for the controls at days 29-45 (estimation).

An abnormal immunological status may also be observed in a young cloned calf after birth, with a sudden and rapid fall in lymphocyte count due to thymic atrophy 6-7 weeks after birth, leading to death on day 51 (Renard et al. [23]). Mice cloned from immature Sertoli cells, and bred in rigorously controlled pathogen-free-conditions died prematurely from pneumonia and reduced production of antibodies compared with that of the controls [17]. Immuno-deficiency has been mentioned incidentally in some other experiments.

\subsection{Telomere length}

There is a general agreement that telomere length regresses with age. Questions have been raised whether organisms created by nuclear transfer with cells from adult and aged animals, will undergo premature senescence. In sheep, Shields et al. [24] observed that in three one-year old sheep cloned with mammary cells from a 6-year old ewe, the telomeres remained shorter compared with the aged-matched animals (terminal restriction fragments (TRF) from $19.14 \mathrm{~kb}$ to $20.37 \mathrm{~kb}$ versus $23.9 \pm 0.18 \mathrm{~kb}$. In contrast to sheep, cloning resets the "telomere clock" in cattle and mice. Lanza et al. [25] have successfully cloned with senescent bovine fibroblasts. Fibroblasts from embryonic tissue, were passaged until greater than $95 \%$ of their life-span were completed. They obtained the birth of 6 calves (out of 1896 nuclear transfers) (Tab. VII).

At senescence, their TRF was decreased from $18.3 \mathrm{~kb}$ at the beginning of the culture,

\footnotetext{
1 "Telomere clock" during the life cycle by analogy with the circadian clock.
} 
to $15.2 \mathrm{~kb}$ at the end. In 7 week-old embryos cloned with these senescent fibroblasts, telomere length was increased to $20.1 \mathrm{~kb}$ and the replicative life-span of cells from these embryos was $90 \pm 1.6$ population doublings versus $60.5 \pm 1.7$ in the primary culture. Finally, the telomeres of 5-10 month old cloned cattle were longer than the telomeres of age-matched control animals. Thus in cattle, cloning over resets telomere length and restores a youthful state. Similar results have been published by Tian et al. [26] who used cells from a 13-year-old cow. All 4 living calves had longer telomeres than the donor cow $(15.38 \pm 0.2 \mathrm{~kb}$ versus $12.43 \pm 0.49 \mathrm{~kb} ; P<0.05)$, and the telomere length of cloned calves was not different from the telomere length of their agematched controls $(15.38 \pm 0.2 \mathrm{~kb}$ versus $14.73 \pm 0.49 \mathrm{~kb}$ ). Miyashita et al. [27] focused their attention on the differences in telomere lengths according to the tissues; they produced reconstructed embryos with nuclei from oviduct or mammary gland epithelial cells, from skin fibroblasts or muscle cells.

Their results are summarized in Table VII. In control Japanese Black males, TRF regresses from $20.5 \mathrm{~kb}$ at birth to $16 \mathrm{~kb}$ in two 18 year-old bulls of the same breed.

It seems that telomere length decreases when donor cells are oviduct epithelial cells, mammary gland and muscle cells. In contrast, telomere length increases when donor cells are ear-skin fibroblasts. Attention might be drawn on the similarity of telomere reduction in calves cloned with fibroblasts from the cow mammary gland, as shown in sheep.

However, the choice of three different breeds of cattle weakens these conclusions.

\subsection{Aberrant patterns of $\mathrm{X}$ chromosome inactivation}

In mice and in cattle, $\mathrm{X}$-inactivation is imprinted in the placenta, in which the paternal $\mathrm{X}$ is preferentially inactivated.
Xue et al. [28] studied allele specific expression of the X-linked monoamine oxydase and nine additional X-linked genes in 9 cloned XX calves. Six calves were born from corona cell nuclear transfer, 4 survived and remained healthy whereas the other two died. In contrast to control calves, they found random $\mathrm{X}$-inactivation in the placenta of the deceased cloned embryos and a completely skewed $\mathrm{X}$-inactivation in that of live clones. They found aberrant expression patterns in nine of the 10 linked genes. In one clone, Xist expression was missing.

Since hypermethylation and hypomethylation of Xist were correlated with the X inactivated and $\mathrm{X}$-activated chromosomes respectively, they examined the methylation patterns of the 5' region of bovine Xist by methylation sensitive PCR. Different degrees of hypomethylation were detected in the hearts in two clones, and in the liver and spleen of one clone.

They believe that the aberrant X-inactivation patterns might result from the fact that somatic cloning bypasses the complete reprogramming process which normally occurs in preimplantation embryos and in germ cells. Consequently epigenetic signals such as DNA methylation, histone acetylation and chromatin structure may or may not be correctly reprogrammed during the process of nuclear remodeling in cattle. Information was missing on the state of methylation of normally imprinted genes immediately after nuclear transfer and during the beginning of cleavage (see Reik [9]).

\subsection{Donor cell types}

The efficiency of cells from many tissues (cumulus, oviduct, uterus, liver, skin, from adult, newborn or embryos) has been studied mainly in cattle for two reasons: the economic interest and the potential number of oocytes available [29]. Similar experiments were developed in mice, also including other cell types (fetal ovary and testis, immature Sertoli cells, spleen, thymus, 
macrophages) from three strains of mice [15]. The overall conclusion is that cultured fetal cells performed better with respect to pregnancy initiation and young born than adult cells with the exception of cumulus cells, which produced the highest overall pregnancy and living young in cattle as well as in mice.

Forsberg et al. [30] have shown that the cell type that combines extended proliferation in culture and a high pregnancy initiation and calving rates, is fetal genital ridge cells (GR). Cultured GR cells derived from presumptive PGC cells from 40-80 day old bovine fetuses, may double as many as 85 times overall in 407 days of culture and up to 75 times after dilution to single-cell culture. After 68 doubling, the BF15c3 cell line maintained a normal caryotype. Culture GR cells used in nuclear transfer initiated pregnancies in $40 \%$ of recipient heifers (197) and 9\% produced living calves (Tab. VIII).

The variability in performance among different GR cell lines was high; one line gave the highest rate of calving (15.2\% of embryos transferred). Although this rate is not better than with that adult cumulus cells, the advantage of GR cells is their broad ability to proliferate in culture that makes them suitable to transfection.

\subsection{Cell cycle stage of the transferred nucleus}

In very few papers the transferred nucleus was really at a precise stage of the cell cycle. As shown by Zou et al. [31] the percentage of goat fibroblasts in G0 + G1 varied according to the type of culture. It was $61.6 \%$ in normal culture medium, $71.7 \%$ after a 3-day starvation in serum-deprived medium, and $74.2 \%$, in confluent cultures. They cloned with cells either in G0 $(\mathrm{G} 0+\mathrm{G} 1$ ?) or in M. They obtained 5 live kids from 32 cloned G0 embryos but no birth when $M(M+G 2$ ? $)$ cells were transferred.

Willmut et al. [32] suggested that induction of nuclear quiescence (stage G0) by serum starvation was critical in allowing donor somatic cells to support the development of sheep cloned embryos. However, almost simultaneously, Liu et al. [33] obtained 3 lambs from morula nuclei in DNA synthesis or in mitosis providing that the enucleated oocytes were at similar stages. The best result was obtained from the transfer of blastomere nuclei in mitosis to metaphase II oocytes.

Ono et al. [16] have shown in mice that even fetal fibroblasts arrested at the metaphase of the cell cycle were able to

Table VIII. Percentage of calves obtained after transfer of cells from different tissues. Results were high with cumulus cells and gonadal ridge cells although variable according to the cell line, and low with adult year cells (Forsberg et al. [29]).

\begin{tabular}{lccccc}
\hline Cell types & $\begin{array}{c}\text { No. of } \\
\text { embryo } \\
\text { transfers }\end{array}$ & $\begin{array}{c}\text { No. of } \\
\text { pregnant } \\
\text { cows }\end{array}$ & $\begin{array}{c}\% \text { of } \\
\text { initiation }\end{array}$ & $\begin{array}{c}\text { No. of } \\
\text { calves }\end{array}$ & $\begin{array}{c}\% \text { calves } \\
\text { per } \\
\text { transfer }\end{array}$ \\
\hline $\begin{array}{l}\text { Gonadal ridge cells } \\
\text { (GR) }\end{array}$ & 197 & 78 & 39.6 & 17 & $9.3-15.2$ \\
$\begin{array}{l}\text { Fetal body cells from } \\
\text { the same embryo as } \\
\text { GR }\end{array}$ & 48 & 23 & 47.9 & 3 & 9.1 \\
Adult ear cells & 142 & 48 & 33.8 & 7 & 5.1 \\
Adult cumulus cells & 34 & 21 & 61.8 & 5 & 15.2 \\
\hline
\end{tabular}


initiate development up to birth. A similar conclusion has been drawn by Zhou et al. [34]. They showed that ES cells in metaphase provided a higher development rate to morula ( 71.8 to $86.7 \%$ ) or blastocyst stages (26.8 to $70 \%)$ than ES cell interphasic nuclei (16.4 to 28.2\%) and (5.9 to $14.1 \%$ ) respectively. Implantation sites were higher and 2 pups were born. ES cells in metaphase were also used in the study of gene expression in cloned mice (see Suemizu et al. [18]).

Vignon et al. [35] obtained a similar percentage of blastocysts from fibroblast nuclei either after starvation or in proliferation and calves were also regularly obtained whatever the cell cycle stage.

Hill et al. [36], studying fetal loss during the first trimester of pregnancy, observed similar pregnancy rates for recipient cows carrying embryos from serum-fed or serum starved nuclei, either at day 30 of pregnancy (46\%, 25/54 and 44\%, 29/66 respectively) or at day $90(4 / 10$ and 6/10).

With pure G1 fibroblasts either from 45-day old bovine fetuses or 4-15 year old adult cattle, Kasinathan et al. [37] obtained 17 to $67 \%$ blastocysts. They transferred pure G1-embryos and also G0-embryos into 50 recipients for each cell-cycle type. The embryonic losses were higher with G0 embryos and finally only G1 embryos gave birth to calves. They also observed that serum starvation was not as efficient as confluence to obtain "pure" G0 nucleus cells.

Thus the postulate that the G0 cell stage is the condition to obtain cloned offspring, is not valid.

\subsection{Abnormal gene expression}

\subsubsection{Embryo}

Daniels et al. [38] compared the transcription of six developmentally important genes (octamer-binding transcription factor 4, $($ Oct-4)); fibroblast growth factors 2 and 4, (FGF2 and FGF4); fibroblast growth factor receptor $2(F G F r 2)$; interleukin 6 , (ILO); GP 130 and polymerase A) in cloned bovine embryos (granulosa cells) and in in vitro fertilized embryos.

Table IX. Transcription of 7 genes in morulas-blastocysts from fertilized or cloned bovine embryos (Daniels [38]).

\begin{tabular}{lccccc}
\hline \multirow{2}{*}{ Gene transcript } & \multicolumn{2}{c}{ In vitro fertilized embryos } & & \multicolumn{2}{c}{ Cloned embryos } \\
\cline { 2 - 3 } \cline { 5 - 6 } Oct-4 & Morula & Blastocyst & & Morula & Blastocyst \\
\hline IL-6 & $6 / 6$ & $6 / 6$ & & $5 / 5$ & $5 / 5$ \\
FGF 2 & $4 / 4$ & $5 / 5$ & & $1 / 4$ & $4 / 4$ \\
FGF 4 & $4 / 4$ & $2 / 4$ & & $2 / 3$ & $3 / 3$ \\
FGF $\boldsymbol{r} 2$ & $7 / 7$ & $10 / 10$ & & $0 / 2$ & $2 / 7$ \\
Gp 130 & $5 / 5$ & $9 / 10$ & & $2 / 6$ & $3 / 6$ \\
Poly $A$ & $16 / 16$ & $5 / 5$ & & $2 / 2$ & $3 / 3$ \\
\hline
\end{tabular}


Morula-blastocyst stage embryos derived from nuclear transfer procedures showed abnormal transcription of IL6, $F G F-4$ and FGFr2 as shown in Table IX. Transcripts of Oct-4, IL-6, FGF-4, FGFr2 are not readily detectable in granulosa cells, however, reprogramming of the somatic cell nucleus is sufficient in NT embryos to produce the correct pattern of embryonic Oct-4 transcription factor. The absence of IL-6 transcripts in 3 of the 4 NT morulae is indicative of a delayed onset of IL-6 transcription in NT embryos. There is also an absence of FGF-4 transcripts in the majority of NT morula - blastocysts. In addition, FGFr2 transcripts are significantly lower in NT embryos. The lack or delayed expression of IL-6, FGF-4 and FGFr2 detected in NT embryos is likely to have significant consequences on the developmental viability of NT embryos. It has been previously shown that mouse embryos that are homozygous for targeted disruptions of the FGF-4 (Feldman et al. [39]) or FGFr2 (Arman et al. [40]) genes, die shortly after implantation although they are able to induce uterine response (decidualization).

A more thorough investigation of $O c t-4$ expression in mouse clones showed anomalies on its distribution [41]. IVF embryos expressed $O c t-4$ after the 4-cell stage, and at the blastocyst stage. This expression is maintained in the inner cell mass (ICM) but down-regulated in the trophectoderm (TE). IVF blastocysts, cultured on the feeder-cell layer, form outgrowths containing Oct-4 expressing cells.

In cumulus cell clones, Oct-4 is expressed at the correct stage ( $>4$-cell stage) but in the majority of the blastocysts, spatial expression is incorrect and maintained in the trophectoderm (55\% vs. 4-13\%). All cloned outgrowths lack Oct-4-mRNAexpressing cells.

Abnormal Oct-4 expression may be associated with aberrant expression of other crucial developmental genes, and Oct-4 levels alone account for the majority of the failures currently observed for somatic cell cloning.

\subsubsection{Placenta}

Humpherys et al. [42] studied, by microarray analysis on RNA, the expression of more than 10000 genes in the placentas of neonatal mice and of neonatal cloned mice derived from nuclear transfer (NT) of either cultured embryonic stem cells (ES) or freshly isolated cumulus cells (Fig. 1).

Using the same technical approach, Suemizu et al. [18] compared the expression of approximately 12000 unique mouse genes in the placentas of ES-cloned mice and of mice from one-cell donor nuclei, as controls ${ }^{2}$. They described the following five abnormal events:

- the expression of some imprinted genes was severely depressed (H19, 10-fold) while $I G F 2$ and $I G F 2 r$ expression was higher (4.8- and 3.2-fold respectively);

- there was altered expression of regulatory genes such as DNA methyltransferase Dnmt-1, Dmnt3a and Dnmt3b, that were upregulated (3.8-fold); similarly, expression of histone acetyl transferase was higher in ES-derived NT placentas than in control placentas;

- there was increased expression of oncogenes and tumor associated protein genes;

- this was overexpression of the gene involved in placental growth, such as Plac-1. Its sustained expression late in gestation and its ectopic expression in spongiotrophoblast cells could contribute to placentomegaly (see Sect. 3.2.1);

- many novel genes were identified, such as Pitrm-1 such a new member of the metalloprotease family. This gene, normally expressed in actively remodeling tissues, such as bone, is abnormallly regulated in ES-derived NT placenta.

${ }^{2}$ ES cell nuclei are pluripotent, and the nuclei of fertilized eggs are totipotent. 

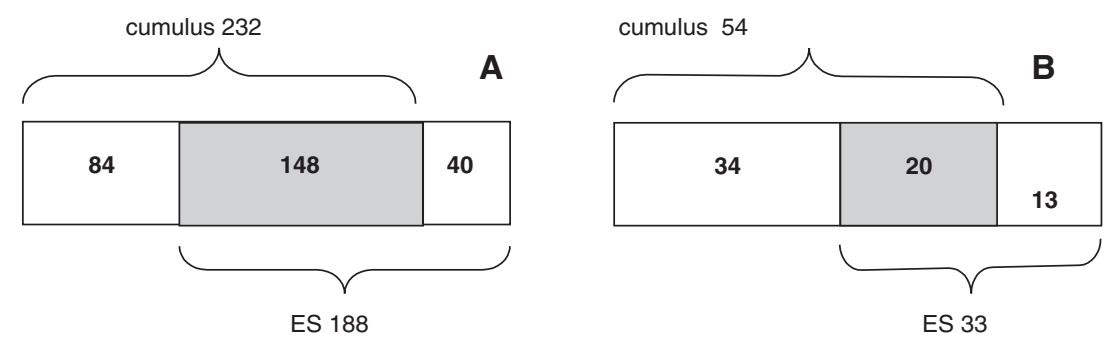

Figure 1. The number of genes that show a 2-fold difference in average expression and differing significantly from controls $(P<0.05)$. Shadowed areas indicated gene expression equally modified in cumulus- and ES cell-derived clones. (A) gene expression reduced in NT placentas; (B) gene expression elevated in NT placentas (from Humpherys et al. [42]).

This impressive list of defective gene expression detected by microarray studies, brings to light the necessity of the following:

- to more thoroughly explore the control of gene expression during normal development;

- to study if these genes are correctly regulated in apparently healthy living cloned animals.

In contrast to ES cell clones, it seems that the changes in expression of the genes IGFII, IGFIIr and H19 do not occur in placentas of clones that are produced from fetal and adult fibroblast cells (Ogura et al. [17]).

\subsection{Imprinting defaults}

Imprinted genes are erased in the primordial germ cell (PGC) before their gametic patterns are re-established during gametogenesis according to the sex of individuals.

Lee et al. [43] studied the development of cloned mouse embryos produced from day 11.5 to day 13.5 PGC. An erasure process occurred between day 10.5 and day 11.5. Cloned embryos produced from day 12.5 to day 13.5 PGC, showed growth retardation and embryonic lethality around day 9.5 of pregnancy. Imprinted genes became biallelic or silent. Cloned embryos produced from day 11.5 PGC survived longer, at least until day 11.5. Several intermediate states of genomic imprinting were seen in these embryos as well as the demethylation status. This means that imprinted genes are not erased simultaneously and that some differences exist between embryos.

\section{ABNORMALITIES INDUCED BY IN VITRO MANIPULATION AND CULTURE}

Some abnormalities described in cloned embryos, placenta and fetuses or the young are relevant to in vitro manipulation and culture. It is interesting to note that cumulus cells which give the highest percentage of success are used without culture. Amongst anomalies observed after cloning with cultured adult cells, the following must be mentionned: telomere shortening, abnormal methylation, aberrant gene expression, large offspring syndrome, and heteroploidy.

\subsection{Telomere shortening}

During in vitro culture of sheep fibroblasts from adult tissue, the telomeres shortened by $157 \mathrm{bp}$ per population doubling [24]. A similar regression of $100 \mathrm{bp}$ per population doubling occurred during the culture of fibroblasts from a 13-year-old dairy cow [26]. 


\subsection{Abnormal methylation}

Shi and Haaf [44] showed that the incidence of abnormal methylation patterns in 2-cell mouse embryos (loss of methylation of one or both nuclei, completely methylated nuclei) differs between in vivo and in vitro fertilized embryos. Methylated DNA was visualized by a well-characterized monoclonal antibody against 5-methyl cytosine $(\mathrm{MeC})$ counterstained with DAPI. When in vitro fertilized eggs were cultured up to the blastocyst stage, the percentage of abnormal methylation varied according to the culture media and the strain (Tab. X).

They found a good correlation between the number of abnormally methylated mouse 2-cell embryos and the embryonic loss during the preimplantation period. Moreover, $95 \%$ of the embryos from non superovulated females developed in culture to the blastocyst stage versus only $86 \%$ of those from superovulated females. These percentages correlated with the abnormal methylation rates, respectively 10 and $20 \%$ of the 2-cell embryos.

\subsection{Lower or delayed gene expression}

Blastocyst formation, pregnancy rates and birth rates are lower than in vivo when oocyte maturation, fertilization and early development occurs in vitro. In order to identify what step is responsible, Knijn et al. [45] studied in bovine embryos, the expression of six marker genes important in development: plakophilin and desmocollin 2 of embryonic origin, glucose transporter 1 , E-cadherin, heat shock protein 70-1, poly A polymerase of both maternal and embryonic origin.

Blastocysts were produced in vitro from oocytes from different follicle sizes: (1) 3-8 mm follicles, (2) preovulatory follicles before LH surge and (3) preovulatory

Table X. Development in vitro of eggs fertilized either in vivo (VVF) or in vitro (IVF) according to the culture medium and the percentages of DNA abnormal methylation (Shi and Haaf [44]).

\begin{tabular}{|c|c|c|c|c|}
\hline \multirow[b]{2}{*}{ Medium } & \multicolumn{2}{|c|}{ In vitro development } & \multicolumn{2}{|c|}{ Methylated DNA (MeC staining) } \\
\hline & No. analysed & $\begin{array}{l}\text { \% developing } \\
\text { to blastocyst }\end{array}$ & No. analysed & $\begin{array}{c}\% \text { with abnormal } \\
\text { methylation } \\
\text { pattern }\end{array}$ \\
\hline (1) IVF mHam F10* & 20 & 20 & 7 & 71 \\
\hline (1) IVF mTC199** & 28 & 75 & 22 & 32 \\
\hline${ }^{(1)}$ IVF M $16 \mathrm{c}^{* * * *}$ & 29 & 83 & 12 & 9 \\
\hline (1) IVF M 16 & 45 & 80 & 18 & 22 \\
\hline (2) IVF M16 & 56 & 72 & 35 & 40 \\
\hline \multicolumn{5}{|l|}{ VVF oocytes from: } \\
\hline Normal females & 40 & 95 & 100 & 10 \\
\hline Superovulated females & 50 & 86 & 30 & 20 \\
\hline
\end{tabular}


follicles $24 \mathrm{~h}$ after the LH surge. Oocytes from groups 1 and 2 were matured in vitro, whereas oocytes from group 3 had undergone their maturation in vivo (4). The control group was composed of blastocysts developed entirely in vivo.

Oocyte maturation in vitro did not modify gene expression. However, fertilization and in vitro culture up to the blastocyst stage induced alterations in the relative abundance of 3 transcripts: expression glucose transporter 1 that was significantly higher $(P<0.05)$ for in vivo blastocysts compared with in vitro blastocysts; desmocollin 2 and plakophilin tended to be higher $(P<0.1)$ whereas no differences were found for heat shock protein 70-1 (see [46]), E-cadherin and poly(A) polymerase.

Thus alterations in the relative abundance of three transcripts in blastocysts produced in vitro cannot primarily be attributed to the origin of the oocyte, but are likely to have been induced by post-maturation or fertilization and culture conditions, or both.

Bertolini et al. [46] investigated the effect of the embryo production system on growth and transcription rate on day 7 and day 16 bovine embryos. In vitro embryos were produced after in vitro maturation of the oocytes in modified TCM 199, fertilization based on the Parish technology, and co-culture with bovine oviductal epithelial cells.

Thirty-four day-7 in vivo (control group) and twenty-eight day-7 in vitro produced embryos (IVP) were non surgically transferred to female recipients synchronous to the donor $( \pm 12 \mathrm{~h})$. In the control group, 18 were transferred as single embryos and 16 were transferred as dual embryos, each in one uterine; from IVP embryos, 14 were transferred as single and 14 as dual embryos.

A wide variability in development and elongation was observed in both groups, however, retarded development, predominantly at the embryonic disc level, was evident in the IVP concepti. The embryonic disc tended to be smaller in female IVP than that of control group female embryos. Incidentally, it must be mentioned that the embryonic disc was larger and the embryo longer in male than in female concepti, irrespective to the group, indicating a well-known fast-growing trend for the male embryos.

The significance of genes examined in this study resides in their close association with embryo growth, development and recognition of pregnancy. Embryonic transcripts of $I G F-I$ and $I G F-I I$, their receptors $I G F-I r$ and $I G F-I I r$, glucose transporters 1 and $3(G l T-1,-3)$, and interferon $\tau$ (inf $\tau)$ were determined by real-time quantitative PCR.

Day 7 IVP embryos presented lower total mRNA levels than the control $(P<0.05)$ but this difference was generally reduced on day 16.

As reported previously by Knijn et al. [45], Day 7 IVP embryos had significantly smaller amounts of transcripts of IGF components (except IGF-I), of glucose transporter-1, transporter-3 and IFN $\tau$ than control embryos.

In conclusion, the in vitro production of bovine embryos negatively affects gene expression on day 7 and the rate of development on day 16.

\subsection{Large offspring syndrome}

The large offspring syndrome (LOS) is observed in bovine, ovine and murine offspring following transfer of in vitro-produced embryos or cloned embryos, and is characterized by a multitude of pathological changes, of which extended gestation length and increased birth weight are predominant features.

It has been clearly shown that LOS is caused by culture conditions during in vitro procedures. Two steps might be involved: fertilization or culture. 
Young et al. [47] collected in vivo ovine zygotes and cultured them in vitro for 5 days before their transfer in recipient ewes. Out of 48 fetuses recovered at day 125 of pregnancy, 12 weighed more than $5 \mathrm{~kg}$ with a maximum weight of $8.2 \mathrm{~kg}$. In these LOS fetuses, expression of IGF-IIr was reduced by $30-60 \%$ relative to the control group and there was a complete loss of methylation in the methylated region of IGF-IIr. These facts suggest that the preimplantation embryo may be vulnerable in culture to epigenetic alterations of imprinted genes.

Sinclair et al. [48] studied the influence of a 5 day culture of in vivo fertilized eggs on the growth of ovine fetuses at day 61 and day 125 of pregnancy. Fetuses derived from co-cultured embryos were $14 \%$ heavier than control fetuses $(P<0.01)$ by day 61 and $34 \%$ heavier $(P<0.001)$ by day 125 of pregnancy. When embryos were cultured in SOF medium, increased weight was lower but remained significant $(P<0.01)$. Thus the LOS did not result from in vitro fertilization, but of the culture of the zygote.

Lazzari et al. [49] analyzed birth weight, and the differences in the following parameters of day 7 and day 12 bovine blastocysts, according to their origin in vivo or in vitro/ in vivo:

- the number of cells in day 7 embryos (Tab. XI);

- the birth weight of calves derived from in vivo and in vitro production (Tab. XII);

Table XI. Number of cells in day 7 bovine embryos after a five day culture (Lazzari et al. [49]).

\begin{tabular}{lcccc}
\hline $\begin{array}{l}\text { Culture media } \\
\text { or in vivo }\end{array}$ & No. of oocytes & $\begin{array}{c}\text { No. of day 7 } \\
\text { blastocysts }\end{array}$ & $\begin{array}{c}\text { Blastocysts / } \\
\text { oocytes (\%) }\end{array}$ & $\begin{array}{c}\text { No. cells / } \\
\text { blastocyst }\end{array}$ \\
\hline SOF-bsa & 830 & 162 & $19.5 \pm 3.1$ & $\mathbf{1 8 3} \pm \mathbf{3 7}$ \\
SOF-serum & 1105 & 200 & $18.1 \pm 4.5$ & $\mathbf{1 7 9} \pm \mathbf{2 3}$ \\
Sheep oviduct & 848 & 180 & $21.6 \pm 2.4$ & $142 \pm 34^{*}$ \\
\hline
\end{tabular}

$* P<0.01$.

Table XII. Gestation length and birth weight in cattle. Abnormal body weight at birth after in vitro culture (Lazzari et al. [49]).

\begin{tabular}{lccc}
\hline Group & No. calves & $\begin{array}{c}\text { Gestation length } \\
\text { days }\end{array}$ & $\begin{array}{c}\text { Birth weight } \\
\mathrm{kg}\end{array}$ \\
\hline SOF-bSA & 23 & $281.1 \pm 7.1^{*}$ & $\mathbf{5 2 . 8 \pm 9 . 4 ^ { * }}$ \\
SOF-serum & 10 & $280.1 \pm 5.9^{*}$ & $\mathbf{5 6 . 7} \pm \mathbf{1 2 . 1 ^ { * }}$ \\
$\begin{array}{l}\text { Early development } \\
\text { in sheep oviduct }\end{array}$ & 34 & $279.2 \pm 5.3^{*}$ & $44.1 \pm 5.5^{* *}$ \\
$\begin{array}{l}\text { In vivo fertilization } \\
\text { and development } \\
\text { (superovulated cows) }\end{array}$ & 63 & $279.4 \pm 5.1^{*}$ & $41.1 \pm 3^{* *}$ \\
$\begin{array}{l}\text { In vivo artificial } \\
\text { insemination }\end{array}$ & 24 & $281.7 \pm 4.3^{*}$ & $43.4 \pm 4.3^{* *}$ \\
\hline
\end{tabular}

$* P<0.01$; ** $P<0.05$. 
Table XIII. Abundance of transcripts of 9 genes in 12-day bovine embryos (Lazzari et al. [49]).

\begin{tabular}{|c|c|c|c|c|}
\hline Transcripts & SOF-bSA & SOF-serum & Sheep oviduct & In vivo \\
\hline Hsp 70.1 & + & $\begin{array}{c}+ \\
P<0.05\end{array}$ & normal & control \\
\hline$S O D$ & $\stackrel{+}{+} P_{0.05}$ & 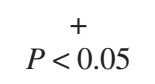 & normal & control \\
\hline Glut-1 & normal & normal & normal & control \\
\hline Glut-3 & $\stackrel{+}{+} P_{0.05}$ & $\stackrel{+}{+}+<_{0.05}$ & $\begin{array}{c}+ \\
P<0.05\end{array}$ & control \\
\hline Glut-4 & $\begin{array}{c}+ \\
P<0.05\end{array}$ & $(+)$ & normal & control \\
\hline IGF1-R & $\stackrel{+}{+}+\stackrel{0.05}{<}$ & $\begin{array}{c}+ \\
P<0.05\end{array}$ & normal & control \\
\hline$I G F 2-R$ & normal & normal & normal & control \\
\hline$B F G$ & $\begin{array}{c}+ \\
P<0.05\end{array}$ & normal & normal & control \\
\hline Histone-4 & normal & normal & normal & control \\
\hline
\end{tabular}

- the relative abundance, in day 12 preimplantation bovine embryos, of the transcripts of genes developmentally important, glucose transporter 1,3 and 4 $(G l T-1,-2,-3,-4), \mathrm{Cu} / \mathrm{Zn}$ superoxyde dismutase (SOD), histone H4.1, bFGF, $I G F-I r$ and IGF-IIr (Tab. XIII).

As shown in Table XI, the percentage of blastocysts was similar whatever the type of culture, however, the number of cells per blastocyst was significantly higher in in vitro culture systems. When the three types of blastocysts were transferred in the recipient cows and developed to term, the duration of gestation was similar in all groups, but birth weights were significantly higher when embryos had been cultured (Tab. XII).

Out of the 9 genes studied, 5 showed a significantly higher level of transcription in in vitro cultured embryos than after early development in the sheep oviduct (Tab. XIII).

Reduced IGF2r protein in mice and sheep is assumed to stimulate growth and to be responsible for LOS. However, the work of Chavatte-Palmer et al. [22] suggests another explanation. In cloned and control calves showing a highly significant difference of body weight at birth $(55.1 \pm 2.7 \mathrm{~kg}$ vs. $43.7 \pm 0.5-45.7 \pm 1.5 \mathrm{~kg}, P<0.001)$, they studied the levels of thyroxin, IGF-I, IGF-II, cortisol and leptin from birth to 7 days. One of the main endocrine differences between cloned and control calves concerns the high level of leptin $(P<0.01)$ in LOS calves. In humans, Koistinen et al. [50], Schubring et al. [51], Matsuda et al. [52], Ong et al. [53], Varvarigou et al. [54] have shown that the concentration of leptin in human cord blood is closely correlated to birth weight and placental weight and that leptin is of placental origin. These observations suggest that LOS calves could result from a hyper secretion of leptin by the placenta.

\subsection{Heteroploidy, mixoploidy}

It is well-known that heteroploidy increases the risk of defective development and abortion. Is this chromosome anomaly 
increased by in vitro fertilization or/and in vitro culture?

Viuff et al. [55-59] studied the ploidy of in vivo and in vitro produced bovine embryos. In both groups, mixoploid embryos were present, and consisted mainly of diploid-triploid cells. Mixoploidy occurred more frequently than polyploidy. From day 2 to day 5 after fertilization of in vivo matured oocytes, there was an increase $(+5-31 \%)$ in the percentage of mixoploid cells. The frequency of polyploidy and mixoploidy of day 3 embryos derived from in vivo matured oocytes was lower than in embryos from in vitro matured oocytes (respectively $1 \%$ versus $6 \%$ and $16 \%$ versus $25 \%$ ).

They followed the evolution of heteroploidy in embryos from in vitro matured oocytes at day 7-8 and day 12 post-fertilization. At day 7-8, some polyploid cells were present in $96 \%$ of the trophectoderm (TE) and in $58 \%$ of the embryonic disc (ED). An average $10.8 \pm 2.2 \%$ and $7.7 \pm$ $2.2 \%$ polyploid cells were found in TE and ED respectively. Embryos were transferred to the uteri on day 7 and then recovered on day 12 . An average of $7.3 \pm 4.4 \%$ and $3.1 \pm$ $2.6 \%$ polyploid cells was found in TE and $\mathrm{ED}$, respectively. Thus there was a decrease in the frequency of polyploid cells from day $7-8$ to day 12 . Unfortunately the levels of heteroploidy on day 7-8 and day 12 in embryos from in vivo matured oocytes were not given.

Booth et al. [58] studied the level of ploidy in day 7 NT blastocysts. Amongst the 112 blastocysts that were analyzed, 26 (23.2\%) possessed completely diploid nuclei and $6(5.4 \%)$ contained only pure polyploid nuclei. The others were mixoploids and the tetraploid state was the predominant condition $(85.5 \%)$.

An inverse relationship between blastocyst total cell number and total percentage of chromosome abnormalities is observed within embryos.
In conclusion, there is a high percentage of chromosome number abnormalities in NT embryos and this percentage is not derived from cumulus donor cells $(0.23 \pm 0.12)$. In vitro maturation of oocytes may increase the percentage of heteroploid cells in concepti, mainly in the trophectoderm.

These observations suggest that the high level of ploidy defects contributes to high and prolonged embryonic losses of nuclear transfer embryos.

\section{CONCLUSION}

This review deals first with the morphological, cellular and genetic abnormalities observed during the development of cloned embryos, fetuses and placenta, and second, what abnormalities are relevant to cloning itself or to the in vitro manipulation. The following conclusions can be drawn.

Abnormal gene expression and methylation, which affect fetuses and placentas as well result in placental hypotrophy or hypertrophy, in errors in imprinting, epigenetic reprogrammation, and in $\mathrm{X}$ inactivation.

With a somatic nucleus at any stage of the cell cycle, cloning is possible provided the recipient egg cytoplasm is at the same stage.

The culture after egg reconstruction and before the transfer to the recipient female, leads to lower or delayed gene expression, to epigenetic modifications and to an increase in the frequency of polyploidy or mixoploidy.

Two approaches have been used to study gene expression: either individual genes known to be important in development such as Oct-4, or thousands of genes by microanalysis on RNA. Oct-4 is overexpressed and its spatial distribution is incorrect. With micro array, clearly important changes have been observed such as over expression of IGF2 /IGF2r, DNMT-1, Dnmt $3 a$ and $3 b$. In the placenta, the specific growth factor 
Plac-1 is also over expressed. These results are somewhat disappointing because around more than one hundred genes are either over or lower expressed in the placenta of living mouse offspring. Apparently these genes are not necessary to fetal development. It has been recently shown in the bacteria, $\mathrm{Ba}$ cillus subtilis, that only 271 of its 4100 genes permit its survival and growth [59]. Thus the interpretation of gene misexpression to determine causes of abnormal development of cloned embryos, fetuses and placentas needs the knowledge, first, of the gene expression in in vivo produced embryos, and second, the evolution of these genes during growth, puberty and reproduction in the surviving cloned offspring.

\section{REFERENCES}

[1] Pace MM, Augenstein ML, Betthauser M et al. Ontogeny of cloned cattle to lactation. Biol Reprod 2002, 67: 334-339.

[2] Tamashiro KL, Wakayama T, Akutsu UH, Yamazaki Y, Lachey JL, Wortman MD, Seeley RJ, D’Alessio DA, Woods SC, Yanagimachi R, Sakai RR. Cloned mice have an obese phenotype not transmitted to their offspring. Nature Med 2002, 8: 262-267.

[3] Heyman Y, Chavatte-Palmer P, Le Bourhis D, Camous S, Vignon X, Renard JP. Frequency and occurrence of late-gestation losses from cattle cloned embryos. Biol Reprod 2002, 66: 6-13.

[4] Renard JP, Zhou QI, Le Bourhis D, Chavatte-Palmer P, Hue I, Heyman Y, Vignon X. Nuclear transfer technologies: between successes and doubts. Theriogenology 2002, 57: 203-222.

15] Gao S, Gasparini B, McGarry M, Ferrier T, Harkness L, De Souza P, Wilmutt Y. Germinal vesicle material is essential for nucleus remodelling after nuclear transfer. Biol Reprod 2002, 67: 928-934.

16] Tani T, Kato Y, Tsunoda Y. Direct exposure of chromosomes to non activated ovum cytoplasm is effective for bovine somatic cell nucleus. Biol Reprod 2001, 64: 324-330.

[7] Kim JM, Ogura A, Nagata M, Aoki F. Analysis of the mechanism for chromatin remodelling in embryo reconstructed by somatic nuclear transfer. Biol Reprod 67, 2002: 760-766.

[8] Loi P, Clinton M, Barboni B, Fulka J, CappaiI P, Feil R, Moor RM, Pyak G. Nuclei of nonviable ovine somatic cells develop into lamb after nuclear transplantation. Biol Reprod 2002, 6: 126-132.

[9] Reik W, Dean W, Walter J. Epigenetic reprogramming in mammalien development. Science 2001, 293: 1089-1093.

[10] Kierszenbaum AL. Genomic imprinting and epigenetic reprogramming: unearthing the garden of forking paths. Mol Reprod Dev 2002, 63: 269-272.

I11] Hata K, Okano M, Lei H, Li E. Dnmt3L cooperates with the Dnmt3 family of de novo DNA methyltransferases to established maternal imprints in mice. Development 2002, 129: 1983-1993.

[12] Cezar GG, Bartolomei MS, Forsberg EJ, First NL, Bishop MD, Eilertsen KJ. Genome-wide alterations in cloned bovine fetuses. Biol Reprod 2003, 68: 1009-1014.

[13] Rybouchkin A, Heindryckx B, Van der Elst J, Dhont M. Developmental potential of cloned mouse embryos reconstructed by a conventional technique of nuclear injection. Reproduction 2002, 124: 197-207.

[14] Koo DB, Kang YK, Choi HE, Sun Paark J, KIM HN, Oh KB, SON DS, Park H, Lee KK, Han YM. Aberrant allocations of inner cell mass and trophectoderm cells in bovine nuclear transfer blastocysts. Biol Reprod 2002, 67: 487-492.

[15] Wakayama T, Yanagimachi R. Mouse cloning with nucleus donor cells of different age and type. Mol Reprod Dev 2001, 58: 376-383.

[16] Ono Y, Shimozawa N, Ito M, Kono T. Cloned mice from fetus fibroblast cells arrested at metaphase by a serial nuclear transfer. Biol Reprod 2001, 64: 44-50.

[17] Ogura A, Inoue K, Ogonuki N, Lee J, Kohda T, Ishino F. Phenotypic effects of somatic cells cloning in the mouse. Clon Stem Cells 2002, 4: 397-405.

[18] Suemizu H, Aiba K, Yoshikawa T, Sharow AA, Shimozawa N, Tamaoki N, Ko MS. Expression profiling of placentomegaly associated with nuclear transplantation of mouse ES cells. Dev Biol 2003, 253: 36-53.

[19] Tanaka S, Oda M, Toyoshima Y, Wakayama T, Tanaka M, Yoshida N, Hattori N, Ohgane J, Yanagimachi R, Shiota K. Placentomegaly in cloned mouse concepti caused by expansion of the spongiotrophoblast layer. Biol Reprod 2001, 65: 1813-1821.

[20] Inoue K, Khoda T, Lee J, Ogonuki N, Mochida K, Noguchi Y, Tenamura K, Kaneko-Ishino T, Ishino F, Ogura A. Faithful expression of imprinted genes in cloned mice. Science 2002, 295 : 297.

[21] Hill JR, Schlafer DH, Fisher PJ, Davies CJ. Abnormal expression of trophoblast major 
histocompatibility complex class I antigens in cloned bovine pregnancies is associated with a pronounced endometrial lymphocytic response. Biol Reprod 2002, 67: 55-63.

[22] Chavatte-Palmer P, Heyman Y, Richard C, Monget P, Le Bourhis D, Kann G,Chillard Y, Vignon X, Renard J. Clinical, hormonal and hematologic characteristics of bovine calves derived from nuclei from somatic cells. Biol Reprod 2002, 66: 1596-1603.

[23] Renard JP, Chastant S, Chesné P, Richard C, Marchal J, Cordonnier N, Chavatte P, Vignon X. Lymphoid hupoplasia and somatic cloning. The Lancet 1999, 353: 1789-1491.

[24] Shiels PG, Kind AJ, Campbell KHS, Waddington D, Wilmutt Y, Colman A, Schnieke AE. Analysis of telomere lengths in cloned sheep. Nature 1999, 399: 316-317.

[25] Lanza RP, Cibelli JB, Blackwell C, Cristopholo VJ, Francis MK, Baerlocher GM, Mak J, Scheritzer M, Chavez EA, Sawyer N, Landsdorp PM, West MD. Extension of cell-life-span and telomere length in animals cloned from senescent somatic cells. Science 2000, 288: 665-669.

[26] Tian XC, Xu J, Yang X. Normal telomere length found in cloned cattle. Nature Genet 2000, 26: 272-273.

[27] Miyashita N, Shiga K, Yonai M, Kaneyama K, Kobayashi S, Kojima T, Goto Y, Khisi M, Aso H, Suzuki T, Sakaguchi M, Nagai T. Remarkable differences in telomere lengths among cloned cattle derived from different cell types. Biol Reprod 2002, 66: 1649-1655.

[28] Xue F, Tian XC, Du F, Kubota C, Tanega M, Dinnyes A, Dai A, Levine H, Pereira LV, Yang $\mathrm{X}$. Aberrant patterns of X-chromosome inactivation in bovine clones. Nature Genet 2002, 31: 216-220.

[29] Kato Y, Tani T, Tsunoda Y. Cloning of calves from various somatic cell types of male and female adult, newborn and fetal cows. J Reprod Fertil 2000, 120: 231-237.

[30] Forsberg EJ, Stelchenko NS, Augenstein ML, Betthauser JM, Childs LA, Eilertsen KJ et al. Production of cloned cattle from in vitro system. Biol Reprod 2002, 67: 327-333.

[31] Zou X, Wang Y, Cheng Y, Yang Y, Ju H, Tang H, Shen Y, Mu Z, Xu S, Du M. Generation of cloned goats (Capra hircus) from transfected fœtal fibroblast cells, the effect of donor cell cycle. Mol Reprod Dev 2002, 61: 164-172.

[32] Wilmut I, Schnieke A, McWhir J, Kind AJ, Campbell KHS. Viable offspring derived from fetal and adult mammalian cells. Nature 1997, 385: 810-813.

[33] Liu L, Dal Y, Moor RM. Nuclear transfer in sheep embryos: the effect of cell cycle coordination between nucleus and cytoplasm and the use of in vitro matured oocytes. Mol Reprod Dev 1997, 47: 255-264.

[34] Zhou Q, Jouneau A, Brochard V, Adenot P, Renard JP. Developmental potential of mouse embryo reconstructed from metaphase embryonic stem cell nuclei. Biol Reprod 2001, 65: 412-419.

[35] Vignon X, Chesné P, Le Bourhis D, Fléchon JE, Heyman Y, Renard JP. Developmental potential of bovine embryos reconstructed from enucleated matured oocytes fused with culture somatic cells. C-R Acad Sci Paris, Sci Vie, 1998, 321: 735-745.

[36] Hill JR, Burghardt RC, Jones K, Long CR, Looney CR, Shin T, Spenver TE, Thompson JA, Winger QA, Westhusin ME. Evidence for placental abnormality as the major cause of mortality in first trimester somatic cell cloned bovine fetuses. Biol Reprod 2000, 63: 1787-1794

[37] Kasinathan P, Knott JG, Wang Z, Jerry DJ, Robl JM. Viable offspring derived from fetal and adult mammalian cells. Nature Biotech 2001, 19: 1176-1178.

[38] Daniels R, Hall V, Trouson AO. Analysis of gene transcription in bovine nuclear transfer embryos reconstructed with granulosa cell nuclei. Biol Reprod 2000, 63: 1034-1040.

[39] Feldman B, Poueymirou W, Papaioannou VE, DeChiara TM, Goldfarb M. Requirement of FGF-4 for post-implantation mouse development. Science 1995, 267: 246-249.

[40] Arman E, Haffner-Krauz R, Chen Y, Heath JK, Lonai P. Targeted disruption of fibroblast growth factor (FGF) receptor 2 suggests a role for FGF signaling in pre-gastrulation mammalian development. PNAS, USA, 1998, 95: 5082-5087.

[41] Boiani M, Eckardt S, Schöller HR, McLaughlin KJ. Oct 4 distribution and level in mouse clones: consequences for pluripotency. Genes Dev 2002, 16: 1209-219.

[42] Humpherys D, Eggan K, Akutsu H, Friedman A, Hochedlinger K, Yanagimachi R, Lander ES, Golub TR, Jaenisch R. Abnormal gene expression in cloned mice derived from embryonic stem cell and cumulus cell nuclei. Proc Natl Acad Sci USA, 2002, 99: 12889-12894.

[43] Lee J, Inoue K, Ono R, Ogonuki N, Khoda T, Kaneko-Ishino T, Ogura A, Ishino F. Erasing genomic imprinting memory in mouse cloned embryos produced from day 121.5 primordial germ cells. Development 2002, 129: 1807-1817.

[44] Shi W, Haaf T. Aberrant methylation patterns at the two-cell stage as an indicator of early developmental failure. Mol Reprod Dev 2002, 63: 329-334.

[45] Knijn HM, Wrenzycki C, Hendriksen PJM, Vos PLAM, Hermann D, Van der Weijden GC, Nieman H, Dieleman SJ. Effects of oocyte 
maturation regimen on the relative abundance of gene transcripts in bovine blastocysts derived in vitro or in vivo. Reproduction 2002, 124: 365-375.

[46] Bertolini M, Beam SW, Shim H, Bertolini LR, Moyer AL Famula TR, Anderson GB. Growth, development and gene expression by in vivoand in vitro-produced day 7 and day 16 bovine embryos. Mol Reprod Dev 2002, 63: 318-328.

[47] Young LE, Fernandez K, McEvoy TG, Butterwith SC, Guteriez CG, Carolan C, Broadbent PJ, Robinson JJ, Wilmut I, Sinclair $\mathrm{KD}$. Epigenetic change in IGF-2R is associated with fetal overgrowth after sheep embryo culture. Nature Genet 2001, 27: 153-154.

[48] Sinclair KD, McEvoy TG, Maxfield EK, Maltin CA, Young LE, Wilmut I, Broadbent PJ, Robinson JJ. Aberrant fetal growth and development after in vitro culture of sheep zygotes. J Reprod Fertil 1999, 116: 177-186.

[49] Lazzari G, Wrenzycki C, Hermann D et al. Cellular and molecular deviation in bovine in viitro-produced embryos are related to the large offspring syndrome. Biol Reprod 2002, 67: 767-775.

[50] Koistinen HA, Koivisto VA, Andersson S, Karonen SL, Kontula K, Oksanen L, Teramo KA. Leptin concentration in cord blood correlates with intrauterine growth. J Clin Endocrinol Metab 1997, 82: 3328-3330.

[51] Schubring C, Kiess W, Englaro P, Rascher W, Dötsch J, Hanitsch S, Attanasio A, Blum WF. Level of leptin in maternal serum, amniotic fluid, and arterial and venous cord blood: relation to neonatal and placental weight. J Clin Endocrinol Metab 1997, 82: 1480-1483.

[52] Matsuda J, Yokota I, Ida M, Murikami T, Naito E, Ito M, Shima K, Kuroda Y. Serum leptin concentration in cord blood: relationship to birth weight and gender. J Clin Endocrinol Metab 1997, 82: 1642-1644.

[53] Ong Ken KL, Ahmed ML, Sherriff A, Woods K A, Watts A, Golding J, Dunger DB. Cord blood leptin is associated with size at birth and predicts infancy weight gain in humans. J Clin Endocrinol Metab 1999, 84: 1145-1148.

[54] Varvarigou A, Manzoros CS, Beratis NG. Cord blood leptin concentrtions in relation to intrauterine growth. Clin Endocrinol 1999, 50: 177-183.

[55] Viuff D, Greve T, Avery B, Hyttel P, Brockhoff $\mathrm{PB}$, Thomsen PD. Chromosome aberrations in in vitro produced bovine embryos at days 2-5 post-insemination. Biol Reprod 2000, 63: 1143-1148.

[56] Viuff D, Hendriksen PJM, Vos PLAM, Dieleman SJ, Bibby BM, Greve T, Hyttel P, Thomsen PD. Chromosomal abnormalities and developmental kinetics in the in vivo-developed cattle embryos at day 2 to 5 after ovulation. Biol Reprod 2001, 65: 204-208.

[57] Viuff D, Palsgaard A, Rickords L, Lawson LG, Greve T, Schmidt M, Avery B, Hyttel P, Thomsen PD. Bovine embryos contain a higher proportion of polyploid cells in the trophectoderm than in the embryonic disc. Mol Reprod Dev 2002, 62: 483-488.

[58] Booth PJ, Viuff D, Shijian T, Holm P, Greve T, Callesen H. Numerical chromosome errors in day 7 somatic nuclear transfer bovine blastocysts. Biol Reprod 2003, 68: 922-928.

[59] Kobayashi K, Ehrlich SD, Albertini A, Amati G, Andersen KK, AsaiK, Ashikaga S, Aymerich S. Essential bacillus subtilis gene. Proc Natl Acad Sci USA 2003, 100: 4678-4683. 